Article

\title{
A New Protocol for the Synthesis of New Thioaryl-Porphyrins Derived from 5,10,15,20-Tetrakis(pentafluorophenyl)porphyrin: Photophysical Evaluation and DNA-Binding Interactive Studies
}

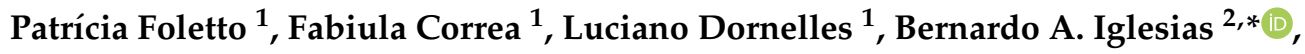 \\ Carolina H. da Silveira ${ }^{2}$, Pablo A. Nogara ${ }^{3}$, João B. T. da Rocha ${ }^{3}$, Maria A. F. Faustino ${ }^{4}$ \\ and Oscar E. D. Rodrigues $1, *$ \\ 1 Departamento de Química, Universidade Federal de Santa Maria, Santa Maria-RS 97105-900, Brazil; \\ patriciafoletto@hotmail.com (P.F.); fabiulacorrea11@gmail.com (F.C.); ldornel@gmail.com (L.D.) \\ 2 Laboratório de Bioinorgânica e Materiais Porfirínicos, Departamento de Química, Universidade Federal de \\ Santa Maria-UFSM, Santa Maria-RS 97105-900, Brazil; carolinahahndasilveira@gmail.com \\ 3 Laboratório de Bioquímica Toxicológica, Departamento de Bioquímica e Biologia Molecular, \\ Univerisidade Federal de Santa Maria, Santa Maria-RS 97105-900, Brazil; \\ pbnogara@gmail.com (P.A.N.); jbtrocha@yahoo.com.br (J.B.T.d.R.) \\ 4 QOPNA and Department of Chemistry, University of Aveiro, Aveiro 3810-193, Portugal; faustino@ua.pt \\ * Correspondence: bernardopgq@gmail.com (B.A.I.); rodriguesoed@smail.ufsm.br (O.E.D.R.); \\ Tel.: +55-55-3220-8761 (B.A.I. \& O.E.D.R.)
}

Academic Editors: M. Graça P. M. S. Neves, M. Amparo F. Faustino and Nuno M. M. Moura Received: 12 September 2018; Accepted: 7 October 2018; Published: 10 October 2018

\begin{abstract}
A new protocol for the preparation of thioaryl-porphyrins is described. The compounds were prepared from different disulfides employing $\mathrm{NaBH}_{4}$ as a reducing agent. The methodology allowed the preparation of four different thioaryl-porphyrins in very-good to excellent yields under soft conditions, such as short reaction times and smooth heating. Additionally, the photophysical properties of new compounds were determined and experimental and theoretical DNA interactions were assessed.
\end{abstract}

Keywords: thioaryl-porphyrins; disulfides; DNA interaction; photophysical characterization

\section{Introduction}

Porphyrins are a useful class of aromatic macrocycles. These compounds have diverse applications, including medicinal [1], electronic devices [2], energy conversion [3], catalysis [4], and others [5-7]. The range of applications for porphyrins can be attributed to some features observed in these molecules, including invariable planar shapes, effective absorption and emission, and high stability under different hazardous conditions [8-11]. Despite the numerous applications for porphyrins, their use in biomedical devices can be highlighted as one of their most prominent features. Porphyrins show photoactivity in some neoplastic diseases [12-17] and can be used as antimicrobial agents [18-21]. The most notable behavior observed in porphyrins to achieve these applications is their ability to generate singlet oxygen species $\left({ }^{1} \mathrm{O}_{2}\right)$ [22]. This process initially involves porphyrin energy absorption and formation of a triplet-excited state. Following this, a transfer of energy from the excited porphyrin to molecular oxygen affords the cytotoxic ${ }^{1} \mathrm{O}_{2}$ species [23-28]. In this context, modulating physicochemical parameters in porphyrins to make them more tunable for specific applications is an exciting and promising field of study. In this context, thioaryl-porphyrins derived 
from 5,10,15,20-tetrakis(pentafluorophenyl)porphyrin $\left(\mathrm{TPPF}_{20}\right)$ are a class of extensively documented porphyrins that have sulfur atoms in their structures. Generally, they are obtained via thiols with high yields and require either long reaction periods, high temperatures or react only with porphyrin complexed with certain metals, such as Zn(II) and Mn(III) [10,29-31].

Based on this, this study aims to describe a new methodology to prepare thioaryl-porphyrins via a reductive cleavage of disulfides in the presence of $\mathrm{TPPF}_{20}$. For this new class of thioaryl-porphyrins, the photophysical parameters were evaluated as well as the ct-DNA interactions by spectroscopic methods (Scheme 1).

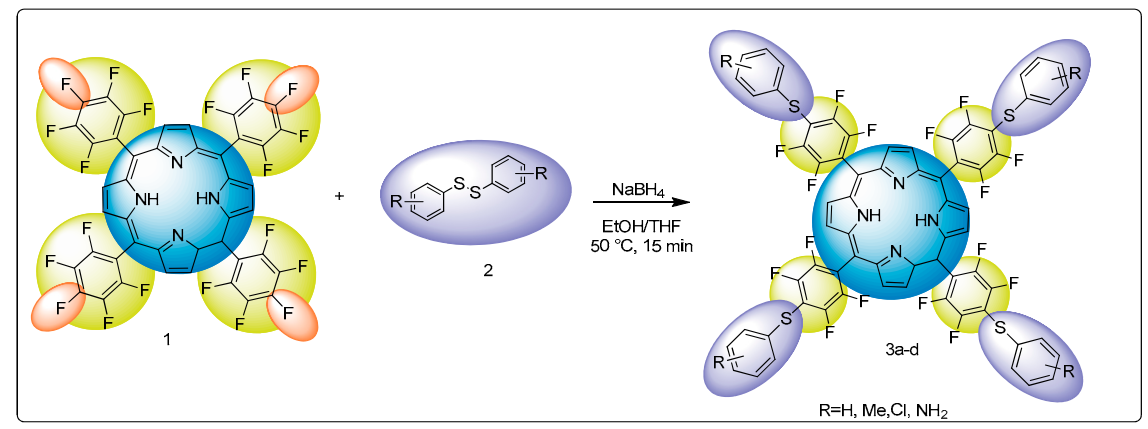

Scheme 1. Synthesis of thioaryl-porphyrins 3a-d.

\section{Results and Discussion}

Diphenyl disulfide and $\mathrm{TPPF}_{20}$ were used as standard to prepare compound 3a and to optimize the reactional conditions. Initially, $\mathrm{TPPF}_{20}(10 \mu \mathrm{mol} ; 10 \mathrm{mg})$, diphenyl disulfide $(80 \mu \mathrm{mol} ; 17.4 \mathrm{mg})$, THF (7 mL), EtOH ( $3 \mathrm{~mL})$, and $\mathrm{NaBH}_{4}(180 \mu \mathrm{mol} ; 6.8 \mathrm{mg})$ were added to a reaction flask. The system was stirred at $50{ }^{\circ} \mathrm{C}$ and the reaction monitored by thin layer chromatography (TLC) for $15 \mathrm{~min}$. In this case, the respective thioaryl-porphyrin 3a was obtained in $84 \%$ yield. In order to find the best reactional condition, disulfide variation was evaluated, while keeping the reaction times. When we reduced the amount of diphenyl disulfide to $40 \mu \mathrm{mol}(8.7 \mathrm{mg})$, the respective compound $3 \mathrm{a}$ was obtained in $70 \%$ yield. Additionally, the effect of time was studied. In this case, when the reaction was carried out in one hour, it afforded thioaryl-porphyrin 3a in 77\% yield. Moreover, decreasing the reaction time to five minutes allowed the preparation of compound 3a in 53\% yield. After optimization, the best reaction was achieved by using $80 \mu \mathrm{mol}$ of diphenyl disulfide for $15 \mathrm{~min}$ at $50{ }^{\circ} \mathrm{C}$.

With the optimal reactional condition established, the versatility of the protocol was explored using different diaryldisulfides, containing either activating or deactivating groups attached to the aromatic ring (Table 1).

The compounds were obtained in very-good to excellent yields for all disulfides used (Table 1). Despite this, the activating groups attached to the aromatic ring in the disulfide portion afforded better yields compared to the deactivating ones. For instance, the activating methyl and amine groups in compounds $\mathbf{3 b}$ and 3d (Table 1, Entries 2 and 4) afforded thioaryl-porphyrins with 92 and 93\% yields, respectively. The presence of a chlorine group attached to the aromatic ring decreased the yield to $82 \%$ (Entry 3). This behavior may be explained by the higher nucleophilicity of the thiolates with activating, instead of deactivating, groups attached to the aromatic ring in the disulfides moieties. 
Table 1. Preparation of thioaryl-porphyrin 3a-d.

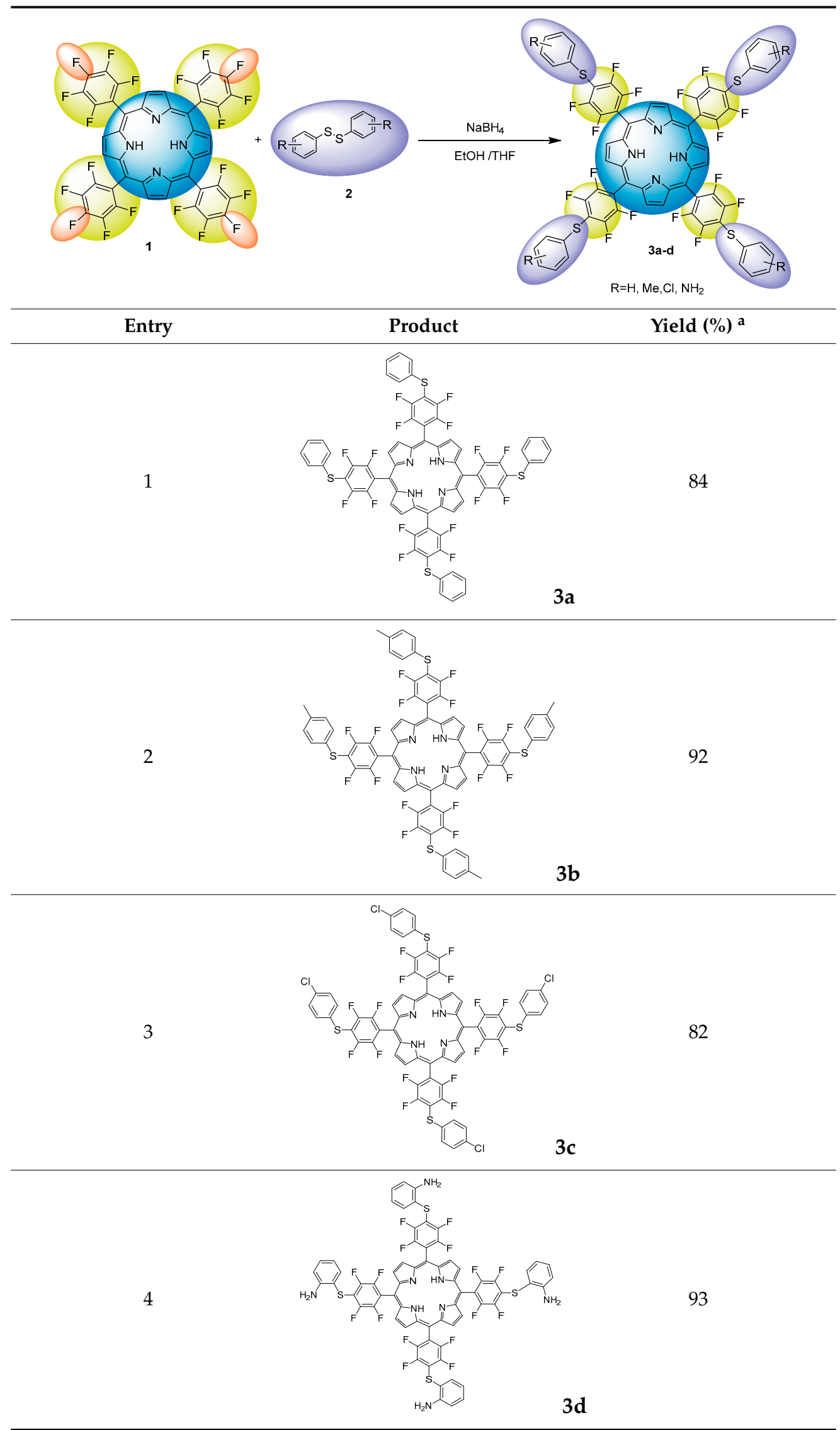

${ }^{a}$ Yields are related to isolated and purified products. 


\subsection{General Absorption and Emission Properties of Thioaryl-Porphyrins 3a-d}

Porphyrins $\mathbf{3 a}-\mathbf{d}$ in chloroform solution show a Soret band transition $\left(\pi \rightarrow \pi^{*}\right.$ macrocycle ring) at about $417 \mathrm{~nm}$ and four vibronic $Q$ band transitions at 508-652 nm (Figure 1). All porphyrins had about the same molar absorptivity ( $\log \varepsilon$; Table 2), which is in agreement with the molecular structures. Moreover, it seems that the aryl-sulfur electron-withdrawing or -donating moiety does not change the band position or peak magnitude, and therefore, it is very likely that it was overlapped by the Soret band intensity.

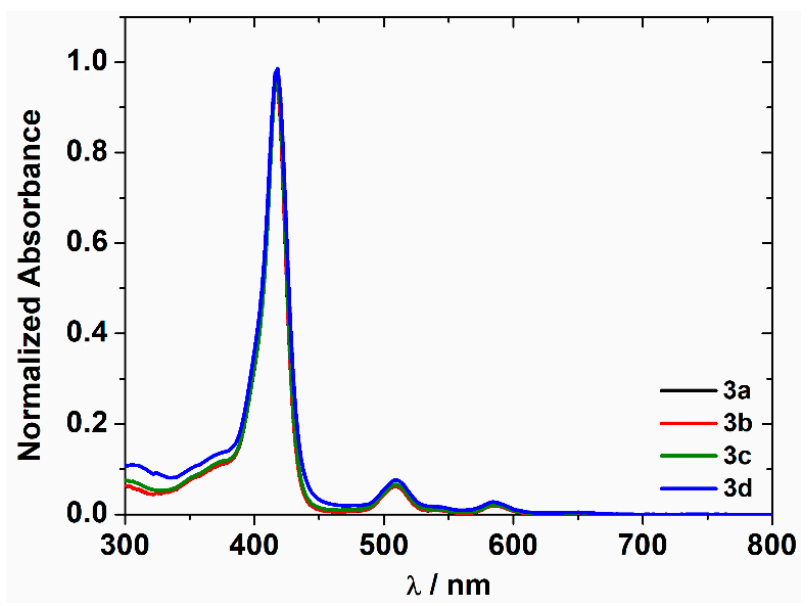

Figure 1. Normalized UV-vis absorption spectra of thioaryl-porphyrins 3a-d containing different substituent groups in $\mathrm{CHCl}_{3}$ solutions.

The emission spectra analysis of thioaryl-porphyrins $\mathbf{3 a - d}$ dissolved in dry chloroform solution $\left(\lambda_{\text {exc }}=418 \mathrm{~nm}\right)$ are shown in Figure 2 and Table 2 . The fluorescence emission quantum yields $\left(\Phi_{\mathrm{f}}\right)$ for sulfur-derivatives were estimated from the reference 5,10,15,20-tetraphenylporphyrin (TPP) by comparative method. The fluorescence quantum yield of molecules indicates the capacity of an excited compound (in the first excited state) to return to the electronic ground state by photon emission. This process depends on the electronic molecular structure, solvent interaction type, and stereochemistry. The values of fluorescence quantum yields were determined at an optical density (OD) in the range 0.01-0.03. By inserting the aryl-sulfur units with different electronic groups at the para-position of the meso-aryl moieties, the fluorescence quantum yield decreased when compared to the TPP standard. This may be explained by the presence of the halogen atoms in the meso-aryl moieties [32]. Moreover, the spin-orbit coupling factor of the halogen atoms decreased radiative channels and increased non-radiative channel processes [32-34].

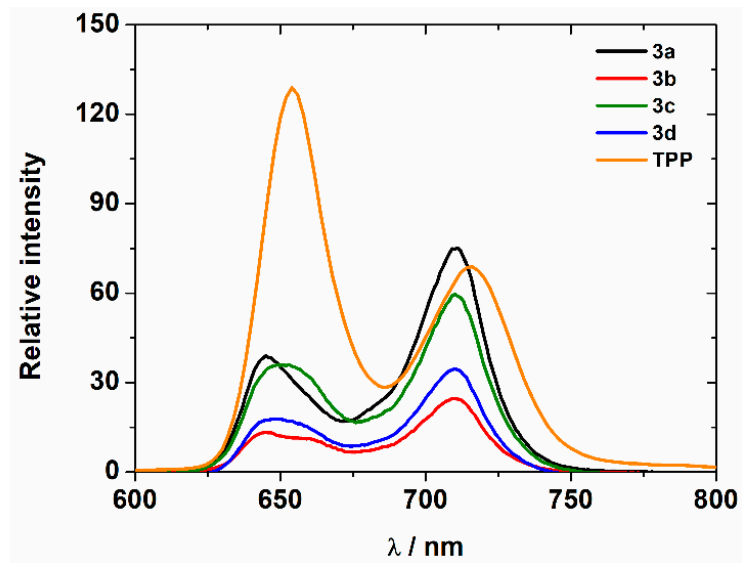

Figure 2. Emission spectra of porphyrin derivatives (excitation at $\lambda_{\mathrm{exc}}=418 \mathrm{~nm}$ ) in argon saturated $\mathrm{CHCl}_{3}$ solutions. 
Table 2. Absorption and emission data of porphyrin derivatives 3a-d.

\begin{tabular}{cccc}
\hline Porphyrin & $\mathbf{n m}, \boldsymbol{\lambda}\left(\mathbf{l o g} \boldsymbol{\varepsilon} ; \mathbf{M}^{-\mathbf{1}} \mathbf{c m}^{-\mathbf{1}}\right)^{\mathbf{a}}$ & Emission $(\mathbf{n m})^{\mathbf{b}}$ & $\mathbf{\Phi}_{\mathbf{f}}{ }^{\mathbf{c}}$ \\
\hline 3a & $417(5.00), 509(3.81), 542(3.00), 585(3.30), 648(2.60)$ & 648,710 & 0.03 \\
3b & $417(5.04), 509(3.85), 540(3.04), 585(3.34), 647(2.65)$ & 648,710 & 0.01 \\
3c & $418(5.02), 508(3.86), 542(3.08), 585(3.36), 652(2.62)$ & 652,710 & 0.02 \\
3d & $418(5.07), 509(3.96), 543(3.30), 584(3.52), 646(2.69)$ & 649,710 & 0.01 \\
\hline
\end{tabular}

${ }^{a}$ Measured in chloroform ([ ] $=10^{-5} \mathrm{M}$ range); ${ }^{\mathrm{b}}$ Measured in dry chloroform solution $\left(\left[\mathrm{]}=2.0 \times 10^{-7} \mathrm{M}\right)\right.$ at $298 \mathrm{~K}$ $\left(\lambda_{\text {exc }}=418 \mathrm{~nm}\right) ;{ }^{\mathrm{c}}$ TPP in DCM as standard $\left(\Phi_{\mathrm{f}}=0.15\right)[35]$.

\subsection{Singlet Oxygen Generation $\left({ }^{1} \mathrm{O}_{2}\right)$ Experiments}

The ability of porphyrins $3 \mathbf{3}-\mathbf{d}$ to produce ${ }^{1} \mathrm{O}_{2}$ was monitored using 1,3-diphenylisobenzofuran (DPBF) in aprotic solvent (DMF) [36]. The DPBF photo-oxidation method has been widely used to quantitatively analyze singlet oxygen production because the reaction product (1,2-dibenzoylbenzene) does not absorb in the visible region. In this assay, changes in DPBF absorbance are directly related to the amount of ${ }^{1} \mathrm{O}_{2}$ generated [37]. This can be observed in Figure 3, in which the first-order kinetic profile of DPBF photo-oxidation in the presence of thioaryl-porphyrin 3a was monitored at $415 \mathrm{~nm}$ during irradiation with a red-light LED array system $(\lambda=635 \mathrm{~nm})$ in DMF solution. One of the important parameters in which to evaluate the photodynamic potential of a photosensitizer is the production of singlet oxygen, $\left(\Phi_{\Delta}\right)$, which is one of the most important reactive oxygen species (ROS) in photophysical and photochemical processes [38]. In this study, the singlet oxygen quantum yield of porphyrins 3a-d was determined, and the values are presented in Table 3. As observed in Table 3, the $\Phi_{\Delta}$ found for compound $\mathbf{3 a}$ is close to the standard TPP and porphyrin $\mathbf{1}$ in several solvents [39-41]. In the case of porphyrins $\mathbf{3} \mathbf{b}-\mathbf{d}$, which have S-aryl units with different substituents $\left(\mathbf{b}: 4-\mathrm{CH}_{3}, \mathbf{c}: 4-\mathrm{Cl}\right.$, $\left.\mathrm{d}: 2-\mathrm{NH}_{2}\right)$, the observed values are smaller than $\operatorname{TPP}\left(\Phi_{\Delta}^{\text {std }}=0.66\right)[38,42]$, although they still displayed an ability to generate singlet oxygen. This behavior could be attributed to electronic deactivation pathways of the excited state due to the presence of the substituents on the thioaryl moieties. Although the ability of sulfur-porphyrin derivatives to generate ${ }^{1} \mathrm{O}_{2}$ is, in general, lower than the TPP or the starting porphyrin 1, all the thioaryl derivatives, after being exposed to red light in the presence of oxygen, demonstrate potential for photodynamic therapy (PDT) applications.

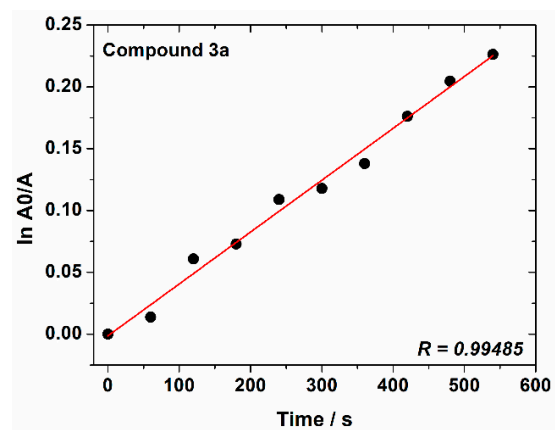

Figure 3. First-order kinetic graphical profile of photodegradation of 1,3-diphenylisobenzofuran (DPBF) by irradiation with LED array system $(\lambda=635 \mathrm{~nm})$ in the presence of thioaryl-porphyrin $3 \mathbf{a}$.

Table 3. Singlet oxygen quantum yields of thioaryl-porphyrins 3a-d.

\begin{tabular}{cc}
\hline Porphyrin & $\boldsymbol{\Phi}_{\Delta}$ \\
\hline 3a & 0.67 \\
3b & 0.10 \\
3c & 0.11 \\
3d & 0.14 \\
TPP & 0.66 \\
* $^{*}$ As standard in DMF solution.; ${ }^{a}$ in benzene. ${ }^{b}$ in dichloromethane; ${ }^{c}$ in toluene.
\end{tabular}




\subsection{Biomolecule Interactive Studies}

\subsubsection{DNA-Binding Assays by Absorption and Emission Analysis}

The interaction of thioaryl-porphyrins 3a-d with ct-DNA has also been studied by UV-vis absorption spectroscopy at the 300-800 nm range in DMSO (1\%)/Tris-HCl buffer solution mixture at $\mathrm{pH}$ 7.4. Thioaryl-porphyrin derivatives interact with DNA and decrease the transition band at a visible range (Soret band). The effect of different ct-DNA concentrations on the Soret and Q-band transitions in the absorption spectrum of compound $\mathbf{3 a}$ (as an example) is presented in Figure 4.

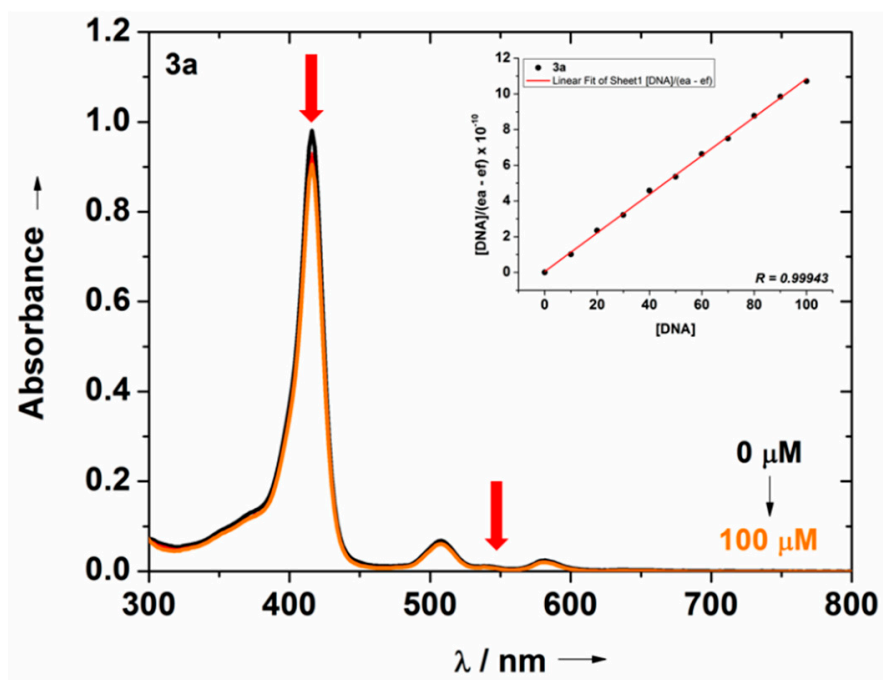

Figure 4. UV-vis titration absorption spectra of thioaryl-porphyrin 3a in a DMSO/Tris-HCl buffer (pH 7.4) mixture. The ct-DNA concentration ranged from 0 to $100 \mu \mathrm{M}$. The insert graph shows the plot of $[\mathrm{DNA}] /\left(\varepsilon_{\mathrm{a}}-\varepsilon_{\mathrm{f}}\right)$ versus [DNA].

In general, upon interaction with the ct-DNA concentration, porphyrin derivatives $\mathbf{3 a}-\mathbf{d}$ revealed distinctive changes (slight hypochromicity; $H \%$ ) in the UV-vis absorption electronic spectra (Table 4). The addition of various ct-DNA concentrations $(0-100 \mu \mathrm{M})$ decreased Soret band intensity. No red shift was observed in any case, which may indicate the non-observed electrostatic interaction of the porphyrin molecules and nucleic acids (Figure 4; Table 4). Furthermore, the changes in intensity of the $\pi \rightarrow \pi^{*}$ Soret transition may be due to the interaction of the aromatic structure of the tetrapyrrolic derivatives, peripheral groups, or both, which is likely because of H-bonding interactions with the DNA nucleobases. This effect is probably caused by the presence of the $\pi$-density macrocycle moiety in the structure that may interact with DNA via hydrophobic interactions, as previously reported for some cases of porphyrin derivatives, and possibly by H-bonding interactions [32,43].

Table 4. DNA-binding data of thioaryl-porphyrin derivatives 3a-d.

\begin{tabular}{ccccccc}
\hline \multirow{2}{*}{ Porphyrin } & \multicolumn{3}{c}{ Absorption } & \multicolumn{3}{c}{ Emission } \\
\cline { 2 - 7 } & $\mathbf{H ( \% )}^{\mathbf{a}}$ & $\boldsymbol{\Delta} \boldsymbol{\lambda} \mathbf{( n m})^{\mathbf{b}}$ & $\left.\mathbf{K}_{\mathbf{b}} \mathbf{( M}^{-\mathbf{1}}\right)^{\mathbf{c}}$ & $\boldsymbol{Q ( \% )} \mathbf{d}$ & $\mathbf{K}_{\mathbf{S V}}\left(\mathbf{M}^{-\mathbf{1}}\right)^{\mathbf{e}}$ & $\left.\boldsymbol{k}_{\mathbf{q}} \mathbf{( s}^{-\mathbf{1}} \mathbf{M}^{-\mathbf{1}}\right)^{\mathbf{f}}$ \\
\hline 3a & 7.65 & 0.0 & $2.08 \times 10^{6}$ & 32.58 & $4.92 \times 10^{3}$ & $2.14 \times 10^{12}$ \\
3b & 4.72 & 0.0 & $1.27 \times 10^{6}$ & 3.60 & $3.30 \times 10^{2}$ & $1.43 \times 10^{11}$ \\
3c & 3.22 & 0.0 & $0.76 \times 10^{6}$ & 21.28 & $2.66 \times 10^{2}$ & $1.15 \times 10^{12}$ \\
3d & 6.31 & 0.0 & $2.86 \times 10^{6}$ & 39.56 & $6.57 \times 10^{3}$ & $2.85 \times 10^{12}$ \\
\hline
\end{tabular}

${ }^{\mathrm{a}} H(\%)=\left(\mathrm{Abs}_{\text {initial }}-\mathrm{Abs}_{\text {final }}\right) /\left(\mathrm{Abs}_{\text {initial }}\right) \times 100($ at Soret band $) ;{ }^{\mathrm{b}} \Delta \lambda(\mathrm{nm})=\lambda_{\text {final }}-\lambda_{\text {initial }}($ at Soret band $) ;{ }^{\mathrm{c}}$ Binding constant by UV-vis ct-DNA analysis; ${ }^{\mathrm{d}} Q(\%)=\left(\right.$ Emission $_{\text {initial }}-$ Emission $\left._{\text {final }}\right) /\left(\right.$ Emission $\left._{\text {initial }}\right) \times 100$; ${ }^{\text {e Stern-Volmer }}$ quenching ethidium bromide-DNA (EB-DNA) constant by emission spectra; ${ }^{\mathrm{f}}$ Stern-Volmer rate quenching EB-DNA constant by emission analysis. 
The constant binding values $\left(\mathrm{K}_{\mathrm{b}}\right)$ of the thioaryl-porphyrins were calculated using Equation (2) (see ESI) (Table 4). In this study, porphyrin derivatives containing S-aryl units demonstrated stronger binding to ct-DNA $\left(\mathrm{K}_{\mathrm{b}} \sim 10^{6} \mathrm{M}^{-1}\right)$, following the increasing order of $\mathrm{K}_{\mathrm{b}}$ data: $3 \mathrm{c}<3 \mathbf{b}<3 \mathbf{a}<3 \mathbf{d}$. All DNA UV-vis titration spectra of thioaryl-porphyrins $\mathbf{3 b}-\mathbf{d}$ are listed in the supporting information (Figures S9-S11).

Competitive-binding assays using the well-known quenching fluorescence method experiment to determine the displacement of the intercalating ethidium bromide (EB) from ct-DNA may provide further confirmation of the binding affinity of the compounds. Emission fluorescence spectra were monitored as increasing concentrations of porphyrins were added by titration to a fixed ct-DA concentration pre-treated with EB (Figure 5).

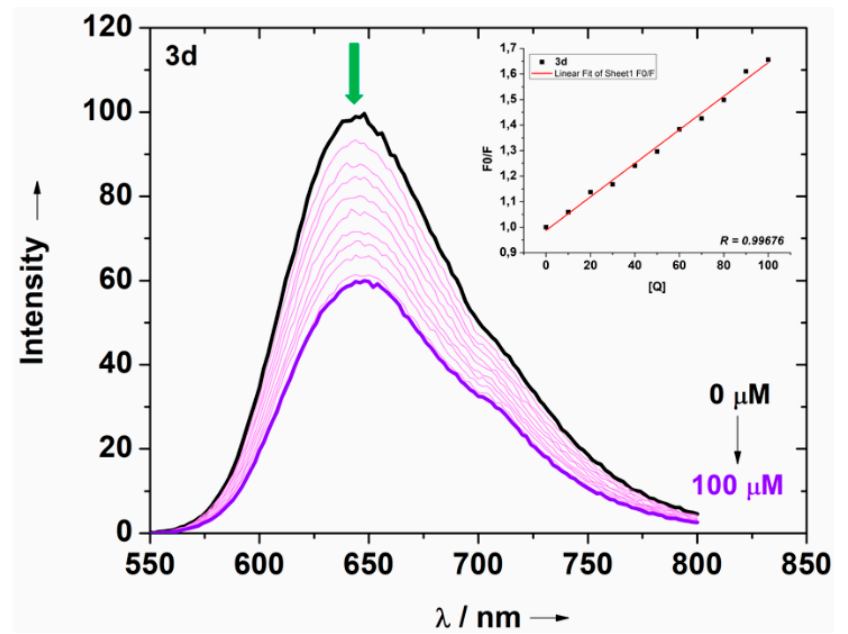

Figure 5. Emission fluorescence spectra of ethidium bromide (EB) bound to ct-DNA in the presence of porphyrin $3 \mathbf{d}$ in a DMSO/Tris-HCl buffer mixture at $\lambda_{\text {exc }}=510 \mathrm{~nm}$. The arrow indicates the changes in fluorescence intensities at increasing sample concentrations. The insert graph shows the plot of $\mathrm{F}_{0} / \mathrm{F}$ versus [ct-DNA].

When thioaryl-porphyrin derivatives were added to the DNA pre-treated with EB, the DNA-induced emission intensity of EB decreased (Figure 5). The EB-DNA interaction with porphyrin 3d showed strong emission at $\lambda_{\mathrm{em}}=644 \mathrm{~nm}$, and, when excited, at $\lambda_{\mathrm{exc}}=510 \mathrm{~nm}$, in addition to also depicting the emission spectra of EB bound to ct-DNA in both the absence and presence of the porphyrin.

These results demonstrate a quenching of the fluorescence intensity of the EB-DNA adduct following the addition of increasing concentrations of porphyrin compounds (Figure 5). This spectral behavior may be attributed to the competition of the porphyrin moiety with the EB intercalator over binding to the DNA structure. In this context, the $\mathrm{K}_{\mathrm{SV}}$ values suggest the competition mode of EB-binding. Moreover, the higher values observed for the quenching constant rate $\left(k_{\mathrm{q}}\right)$ indicated a static interaction between the porphyrins and DNA (Table 4).

The inset graphs in Figure 5 show the Stern-Volmer plot, which was obtained as the relationship between $\mathrm{F}_{0} / \mathrm{F}$ and ct-DNA concentrations. The quenching Stern-Volmer constant $\left(\mathrm{K}_{\mathrm{SV}}\right)$ and quenching constant rate $\left(k_{\mathrm{q}}\right)$ values are presented in Table 4 . Moreover, EB-DNA emission spectra of derivatives 3a-c are listed in the supporting information section (Figures S12-S14).

\subsubsection{DNA Molecular Docking with Thioaryl-Porphyrins 3a-d}

A molecular docking simulation was carried out in order to better understand the interactions of compounds 3a-d with DNA. The molecular docking with DNA showed that thioaryl-porphyrin derivatives interact in the minor groove region with a very similar binding pose (Figure 6). All molecules bind in the region between the nucleoside residues deoxyadenosine-7 (dG-7), deoxythymidine-8 (dT-8), deoxycytidine-9 (dC-9) from the DNA chain A, deoxyadenosine-20 (dG-20), 
deoxycytidine-21 (dC-21) and deoxyguanosine-22 (dG-22) from DNA chain B (Figure 6, left side). In fact, some studies have even indicated that thioaryl-porphyrin hybrids can bind to the minor groove of DNA $[44,45]$.

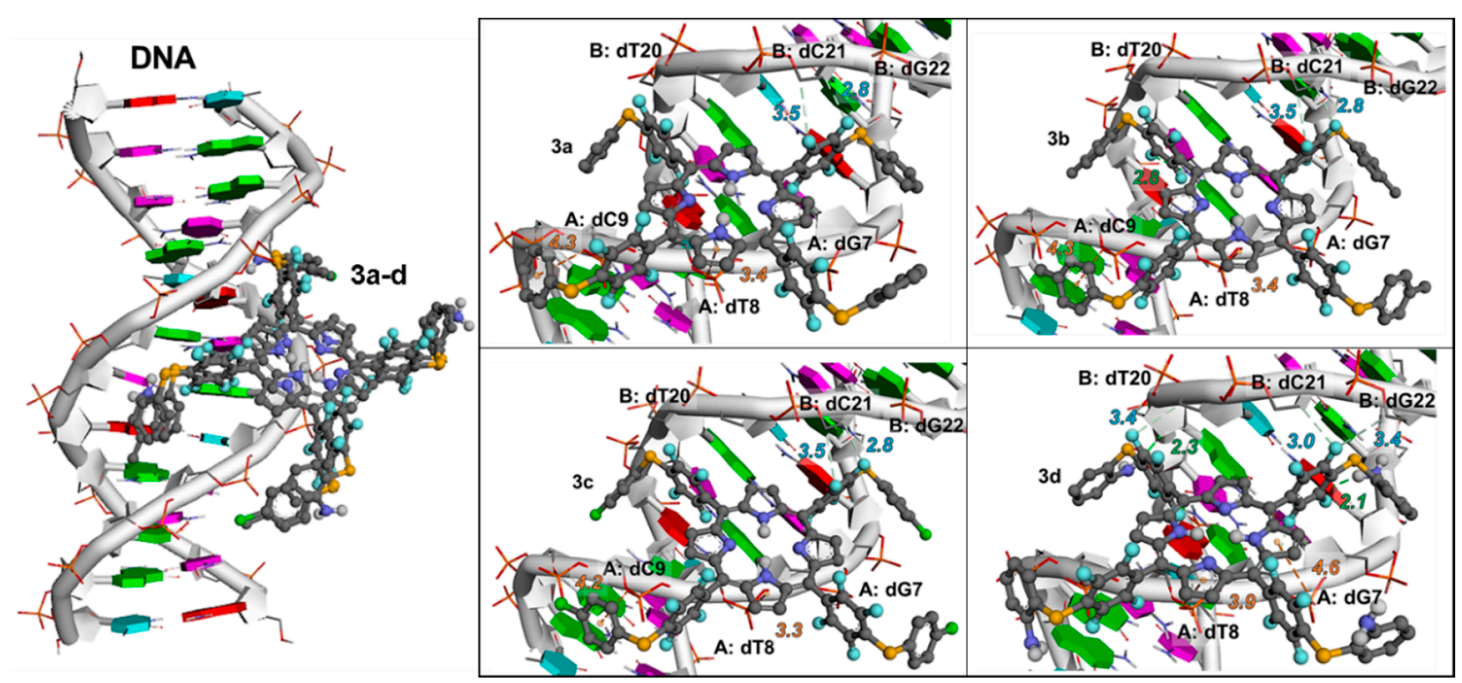

Figure 6. Overview of the interactions between DNA and compounds 3a-d. Both compounds interact in the minor groove region of the DNA. The dotted lines represent the respective interactions: green indicates $\mathrm{H}$-bonds; orange represents the $\pi$-anion interactions; light blue indicates carbon-hydrogen bonds. Rings in red, blue, pink, and green (in DNA) indicate deoxyadenosine (dG), deoxythymidine $(\mathrm{dT})$, deoxycytidine $(\mathrm{dC})$, and deoxyguanosine $(\mathrm{dG})$, respectively. The distances of the interactions are in $\AA$.

In general, the compounds showed electrostatic $\pi$-anion interactions between the phosphate groups (from DNA) and the pyrrolic and aryl ring from compounds $3 \mathbf{a}-\mathbf{d}$, in addition to H-bonds between the fluorine group and an amino moiety from the DNA bases. These observations indicate that the substituent groups do not significantly interfere in the interactions, despite compound $\mathbf{3} \mathbf{d}$ (which possesses the ortho-amino group) presenting more $\mathrm{H}$-bonds with the DNA. In addition, we observed the importance of the carbon-hydrogen bond with the fluorine moiety (C-H $\cdots$ F-C) [46-49] as an interaction that stabilizes the thioaryl-porphyrins-DNA adduct. The predicted theoretical thermodynamic data $\left(\Delta \mathrm{G}_{\text {bind }}\right)$ indicated that all the thioaryl-porphyrin derivatives present spontaneous interaction with DNA fragments $(3 \mathbf{a}(-8.8 \mathrm{kcal} / \mathrm{mol}) ; 3 \mathbf{b}(-9.3 \mathrm{kcal} / \mathrm{mol}) ; 3 \mathbf{c}(-9.3 \mathrm{kcal} / \mathrm{mol})$; $3 \mathbf{d}(-8.8 \mathrm{kcal} / \mathrm{mol}))$. This is probably due to the steric hindrance of the thioaryl-porphyrin derivatives since they bind to the minor groove of DNA and do not intercalate [49].

\section{Materials and Methods}

Chemistry: Hydrogen nuclear magnetic resonance $\left({ }^{1} \mathrm{H}-\mathrm{NMR}\right)$ spectra were obtained on a Bruker Avance III spectrometer, that operate on the frequency of $600 \mathrm{MHZ}$ to hydrogen, at the Universidade Federal de Santa Maria. Spectra were recorded in $\mathrm{CDCl} 3$ solutions. Chemical shifts are reported in parts per million, referenced to the solvent peak of TMS. Data are reported as follows: chemical shift (d), multiplicity ( $\mathrm{s}=$ singlet, $\mathrm{d}=$ doublet, $\mathrm{dd}=$ double doublet, $\mathrm{t}=$ triplet $\mathrm{m}=$ multiplet), and coupling constant $(\mathrm{J})$ in hertz and integrated intensity. Fluor-19 nuclear magnetic resonance $\left({ }^{19} \mathrm{~F}\right)$ spectra were obtained at $565 \mathrm{MHz}$. Spectra were recorded in $\mathrm{CDCl} 3$ solutions and $\mathrm{C} 6 \mathrm{~F} 6$ as external reference. High resolution mass spectra: Samples were diluted in methanol, containing $100 \mu \mathrm{L}$ of $200 \mathrm{mM}$ $\mathrm{NH} 4 \mathrm{OH}$. Analyses were performed by infusion mode in an ACQUITYTMUPLC system from Waters Corp. (Milford, MA, USA) equipped with sampler manager and quadrupole time of flight (Q-Tof) MS detector. The Q-Tof Xevo G2 mass spectrometer was equipped with an electrospray ionization source (ESI). Detections were performed in positive ion mode (ESI+) and resolution mode. Optimized MS 
conditions were: capillary voltage $2.50 \mathrm{kV}$, cone voltage $112 \mathrm{~V}$, extractor cone $4.5 \mathrm{~V}$, desolvation gas $500 \mathrm{~L} / \mathrm{h}$, cone gas $10 \mathrm{~L} / \mathrm{h}$, desolvation temperature $400{ }^{\circ} \mathrm{C}$, and source temperature $150{ }^{\circ} \mathrm{C}$. Acquisition mass range was monitored from 50 to $1800 \mathrm{Da}$. System control and data acquisition were performed using MassLynx V 4.1 software.

\section{General Procedure for the Synthesis 3a-d}

In a Schlenk tube under an argon atmosphere, $0.08 \mathrm{mmol}$ of the respective diaryldisulfide, THF $(7 \mathrm{~mL})$, sodium borohydride $(180 \mu \mathrm{mol} ; 6.8 \mathrm{mg})$, and ethanol $(3 \mathrm{~mL})$ were added. After $1 \mathrm{~min}$, TPP-F20 $(10 \mu \mathrm{mol} ; 10 \mathrm{mg}) 1 \mathrm{was}$ added, and the resulting mixture was stirred at $50{ }^{\circ} \mathrm{C}$ for $15 \mathrm{~min}$. The reaction was quenched with $10 \mathrm{~mL}$ of water, and the aqueous layer was extracted with $\mathrm{CH}_{2} \mathrm{Cl}_{2}$. The combined organic extracts were dried over $\mathrm{MgSO}_{4}$, filtered and evaporated to dryness. The crude products were purified in a silica gel TLC for chromatographic purification, using hexane-ethylacetate (70:20) as the eluent, affording the pure porphyrin 3a-d.

5,10,15,20-tetrakis[4-(phenylthio)-2,3,5,6-tetrafluorophenyl]porphyrin (3a). Physical state: purple solid. Yield: $10.9 \mathrm{mg}, 84 \% .{ }^{1} \mathrm{H}-\mathrm{NMR}(600 \mathrm{MHz}, \mathrm{CDCl} 3) \delta 8.91(\mathrm{~s}, 8 \mathrm{H}), 7.70(\mathrm{~d}, J=6 \mathrm{~Hz}, 8 \mathrm{H}), 7.41-7.49$ $(\mathrm{m}, 12 \mathrm{H}),-2.85(\mathrm{~s}, 2 \mathrm{H}) \mathrm{ppm} .{ }^{19} \mathrm{~F}-\mathrm{NMR}(565 \mathrm{MHz}, \mathrm{CDCl} 3) \delta-132.87\left(\mathrm{dd}, J_{1}=22.6, J_{2}=11.3 \mathrm{~Hz}\right.$, F ortho), -136.29 (dd, $J_{1}=22.6, J_{2}=11.3 \mathrm{~Hz}, \mathrm{~F}$ meta) ppm. HRMS-ESI: $m / z$ calcd to to $\mathrm{C}_{68} \mathrm{H}_{30} \mathrm{~F}_{16} \mathrm{~N}_{4} \mathrm{~S}_{4}$ $[\mathrm{M}+\mathrm{H}]^{+} ; 1335.1176$ found:1335.1223.

5,10,15,20-tetrakis[-(4-methylphenylthio)-2,3,5,6-tetrafluorophenyl]porphyrin (3b). Physical state: purple solid. Yield: $12 \mathrm{mg}, 92 \% .{ }^{1} \mathrm{H}-\mathrm{NMR}(600 \mathrm{MHz}, \mathrm{CDCl} 3) \delta 8.90(\mathrm{~s}, 8 \mathrm{H}), 7.65(\mathrm{~d}, \mathrm{~J}=6 \mathrm{~Hz}, 8 \mathrm{H}), 7.29$ $(\mathrm{d}, J=6 \mathrm{~Hz}, 8 \mathrm{H}), 2.44(\mathrm{~s}, 12 \mathrm{H}),-2.91(\mathrm{~s}, 2 \mathrm{H}) .{ }^{19} \mathrm{~F}-\mathrm{NMR}(565 \mathrm{MHz}, \mathrm{CDCl} 3) \delta-133.28\left(\mathrm{dd}, J_{1}=28.2\right.$, $J_{2}=11.3 \mathrm{~Hz}, \mathrm{~F}$ ortho $),-136.49\left(\mathrm{dd}, J_{1}=28.2, J_{2}=11.3 \mathrm{~Hz}, \mathrm{~F}\right.$ meta $)$ ppm. HRMS-ESI: $m / z$ calcd to $\mathrm{C}_{72} \mathrm{H}_{38} \mathrm{~F}_{16} \mathrm{~N}_{4} \mathrm{~S}_{4}[\mathrm{M}+\mathrm{H}]^{+} ; 1391.1802$ found: 1391.1873 .

5,10,15,20-tetrakis[4-(4-chlorophenylthio)-2,3,5,6-tetrafluorophenyl]porphyrin (3c). Physical state: purple solid. Yield: $10.7 \mathrm{mg}, 82 \% .{ }^{1} \mathrm{H}-\mathrm{NMR}(600 \mathrm{MHz}, \mathrm{CDCl} 3) \delta 8.90(\mathrm{~s}, 8 \mathrm{H}), 7.66(\mathrm{~d}, J=6 \mathrm{~Hz}, 8 \mathrm{H}), 7.47$ $(\mathrm{d}, J=6 \mathrm{~Hz}, 8 \mathrm{H}),-2.89(\mathrm{~s}, 1 \mathrm{H}) .{ }^{19} \mathrm{~F}-\mathrm{NMR}(565 \mathrm{MHz}, \mathrm{CDCl} 3) \delta-132.80\left(\mathrm{dd}, J_{1}=22.6, J_{2}=11.3 \mathrm{~Hz}\right.$, $\mathrm{F}$ ortho),$-135.90\left(\mathrm{dd}, J_{1}=22.6, J_{2}=11.3 \mathrm{~Hz}, \mathrm{~F}\right.$ meta) ppm. HRMS-ESI: $m / z$ calcd to $\mathrm{C}_{68} \mathrm{H}_{26} \mathrm{Cl}_{4} \mathrm{~F}_{16} \mathrm{~N}_{4} \mathrm{~S}_{4}$ $[\mathrm{M}+\mathrm{H}]^{+} ; 1472.9588$ found: 1472.9628 .

5,10,15,20-tetrakis[4-(2-aminophenylthio)-2,3,5,6-tetrafluorophenyl]porphyrin (3d). Physical state: purple solid. Yield: $12.9 \mathrm{mg}, 93 \% .{ }^{1} \mathrm{H}-\mathrm{NMR}(600 \mathrm{MHz}, \mathrm{CDCl} 3) \delta 8.86(\mathrm{~s}, 8 \mathrm{H}), 7.83-7.81(\mathrm{~m}, 4 \mathrm{H}), 7.32-7.29$ $(\mathrm{m}, 4 \mathrm{H}), 6.88-6.83(\mathrm{~m}, 8 \mathrm{H}), 4.68(\mathrm{~s}, 8 \mathrm{H})-2.96(\mathrm{~s}, 2 \mathrm{H}) .{ }^{19} \mathrm{~F}-\mathrm{NMR}(565 \mathrm{MHz}, \mathrm{CDCl} 3) \delta-133.78(\mathrm{dd}$, $J_{1}=28.2, J_{2}=11.3 \mathrm{~Hz}, \mathrm{~F}$ ortho $),-136.53\left(\mathrm{dd}, J_{1}=28.2, \mathrm{~J}_{2}=11.3 \mathrm{~Hz}, \mathrm{~F}\right.$ meta $)$ ppm. HRMS-ESI: $m / z$ calcd to C68H34F16N8S4 [M + H] ${ }^{+}$; 1395.1612 found: 1395.1611.

\section{Conclusions}

The synthesis of thioaryl-porphyrins using a new synthetic protocol was disclosed. The methodology enabled the preparation of four porphyrins in very-good to excellent yields under soft conditions. The new compounds presented good photophysical properties to be considered as photosensitizers for photodynamic therapy. Additionally, experimental and theoretical DNA interactive assays were performed, showing an effective interaction between thioaryl-porphyrin hybrids and DNA.

Supplementary Materials: The following are available online. Experimental procedures, characterization of compounds, DNA UV-vis absorption spectra, EB DNA emission fluorescence spectra.

Author Contributions: P.F., F.C., L.D., M.A.F.F. and O.E.D.R. designed and developed the synthesis of the thioaryl-porphyrins. B.A.I. and C.H.d.S. performed the photophysical evaluations. P.A.N. and J.B.T.d.R. performed the docking studies. 
Funding: The authors gratefully acknowledge CAPES, CNPq (Ed. Universal 400791/2016-1, Produtividade em Pesquisa-303387/2015-7, Pesquisador visitante-401397/2014-9).

Acknowledgments: The authors gratefully acknowledge CAPES and CNPq. Thanks are also due to the University of Aveiro, to FCT/MEC for the financial support of QOPNA research Unit (FCT UID/QUI/00062/2013), through national funds and when applicable co-financed by the FEDER, within the PT2020 Partnership Agreement and "Compete" 2020, and also to the Portuguese NMR Network.

Conflicts of Interest: The authors declare no conflict of interest.

\section{References}

1. Slomp, A.M.; Barreira, S.M.W.; Carrenho, L.Z.B.; Vandresen, C.C.; Zattoni, I.F.; Ló, S.M.S.; Dallagnol, J.C.C.; Ducatti, D.R.B.; Orsato, A.; Duarte, M.E.R.; et al. Photodynamic effect of meso-(aryl)porphyrins and meso-(1-methyl-4-pyridinium)porphyrins on HaCaT keratinocytes. Bioorg. Med. Chem. Lett. 2017, 27, $156-161$. [CrossRef] [PubMed]

2. Senge, M.O.; Fazekas, M.; Notaras, E.G.A.; Blau, W.J.; Zawadzka, M.; Locos, O.B.; Ni Mhuircheartaigh, E.M. Nonlinear optical properties of porphyrins. Adv. Mater. 2007, 19, 2737-2774. [CrossRef]

3. Guldi, D.M. Fullerene-porphyrin architectures; photosynthetic antenna and reaction center models. Chem. Soc. Rev. 2002, 31, 22-36. [CrossRef] [PubMed]

4. Castro, K.A.D.F.; Figueira, F.; Mendes, R.F.; Cavaleiro, J.A.S.; da Neves, M.G.P.M.S.; Simões, M.M.Q.; Almeida Paz, F.A.; Tomé, J.P.C.; Nakagaki, S. Copper-porphyrin-metal-organic frameworks as oxidative heterogeneous catalysts. ChemCatChem 2017, 9, 2939-2945. [CrossRef]

5. Stich, M.I.J.; Fischer, L.H.; Wolfbeis, O.S. Multiple fluorescent chemical sensing and imaging. Chem. Soc. Rev. 2010, 39, 3102-3114. [CrossRef] [PubMed]

6. Drain, C.M.; Russell, K.C.; Lehn, J.M. Self-assembly of a multi-porphyrin supramolecular macrocycle by hydrogen bond molecular recognition. Chem. Commun. 1996, 337-338. [CrossRef]

7. Walter, M.G.; Rudine, A.B.; Wamser, C.C. Porphyrins and phthalocyanines in solar photovoltaic cells. J. Porphyr. Phthalocyanines 2010, 14, 759-792. [CrossRef]

8. Quiroz-Segoviano, R.I.Y.; Serratos, I.N.; Rojas-González, F.; Tello-Solís, S.R.; Sosa-Fonseca, R.; Medina-Juárez, O.; Menchaca-Campos, C.; García-Sánchez, M.A. On tuning the fluorescence emission of porphyrin free bases bonded to the pore walls of organo-modified silica. Molecules 2014, 19, 2261-2285. [CrossRef] [PubMed]

9. George, C.D.; Richardson, T.; Hofton, M.E.; Vale, C.M. Chlorine gas sensing using thin films of meso-tetra ž p-stearamidophenyl/porphyrin. Mater. Sci. Eng. 1999, 8-9, 559-563. [CrossRef]

10. Costa, J.I.T.; Tomé, A.C.; Neves, M.G.P.M.S.; Cavaleiro, J.A.S. 5,10,15,20-Tetrakis(pentafluorophenyl) porphyrin: A versatile platform to novel porphyrinic materials. J. Porphyr. Phthalocyanines 2011, 15, 1116-1133. [CrossRef]

11. Aratani, N.; Takagi, A.; Yanagawa, Y.; Matsumoto, T.; Kawai, T.; Yoon, Z.S.; Kim, D.; Osuka, A. Giant meso-meso-linked porphyrin arrays of micrometer molecular length and their fabrication. Chem. A Eur. J. 2005, 11, 3389-3404. [CrossRef] [PubMed]

12. Bhupathiraju, N.V.S.D.K.; Hu, X.; Zhou, Z.; Fronczek, F.R.; Couraud, P.O.; Romero, I.A.; Weksler, B.; Vicente, M.G.H. Synthesis and in vitro evaluation of BBB permeability, tumor cell uptake, and cytotoxicity of a series of carboranylporphyrin conjugates. J. Med. Chem. 2014, 57, 6718-6728. [CrossRef] [PubMed]

13. Pereira, P.M.R.; Silva, S.; Bispo, M.; Zuzarte, M.; Gomes, C.; Girão, H.; Cavaleiro, J.A.S.; Ribeiro, C.A.F.; Tomé, J.P.C.; Fernandes, R. Mitochondria-targeted photodynamic therapy with a galactodendritic chlorin to enhance cell death in resistant bladder cancer cells. Bioconjug. Chem. 2016, 27, 2762-2769. [CrossRef] [PubMed]

14. Gomes, A.T.P.C.; Neves, M.G.P.M.S.; Cavaleiro, J.A.S. Cancer, photodynamic therapy and porphyrin-type derivatives. An. Acad. Bras. Cienc. 2018, 90, 993-1026. [CrossRef] [PubMed]

15. Abrahamse, H.; Hamblin, M.R. New photosensitizers for photodynamic therapy. Biochem. J. 2016, 473, 347-364. [CrossRef] [PubMed]

16. Pereira, P.M.R.; Carvalho, J.J.; Silva, S.; Cavaleiro, J.A.S.; Schneider, R.J.; Fernandes, R.; Tomé, J.P.C. Porphyrin conjugated with serum albumins and monoclonal antibodies boosts efficiency in targeted destruction of human bladder cancer cells. Org. Biomol. Chem. 2014, 12, 1804-1811. [CrossRef] [PubMed] 
17. Pereira, P.M.R.; Silva, S.; Ramalho, J.S.; Gomes, C.M.; Girão, H.; Cavaleiro, J.A.S.; Ribeiro, C.A.F.; Tomé, J.P.C.; Fernandes, R. The role of galectin-1 in in vitro and in vivo photodynamic therapy with a galactodendritic porphyrin. Eur. J. Cancer 2016, 68, 60-69. [CrossRef] [PubMed]

18. Tavares, A.; Dias, S.R.S.; Carvalho, C.M.B.; Faustino, M.A.F.; Tomé, J.P.C.; Neves, M.G.P.M.S.; Tomé, A.C.; Cavaleiro, J.A.S.; Cunha, Â.; Gomes, N.C.M.; et al. Mechanisms of photodynamic inactivation of a Gram-negative recombinant bioluminescent bacterium by cationic porphyrins. Photochem. Photobiol. Sci. 2011, 10, 1659-1669. [CrossRef] [PubMed]

19. Diogo, P.; Fernandes, C.; Caramelo, F.; Mota, M.; Miranda, I.M.; Faustino, M.A.F.; Neves, M.G.P.M.S.; Uliana, M.P.; de Oliveira, K.T.; Santos, J.M.; et al. Antimicrobial photodynamic therapy against endodontic Enterococcus faecalis and Candida albicans mono and mixed biofilms in the presence of photosensitizers: A comparative study with classical endodontic irrigants. Front. Microbiol. 2017, 8, 1-11. [CrossRef] [PubMed]

20. Marciel, L.; Teles, L.; Moreira, B.; Pacheco, M.; Lourenço, L.M.O.; Neves, M.G.P.M.S.; Tomé, J.P.C.; Faustino, M.A.F.; Almeida, A. An effective and potentially safe blood disinfection protocol using tetrapyrrolic photosensitizers. Future Med. Chem. 2017. [CrossRef] [PubMed]

21. Mesquita, M.Q.; Dias, C.J.; Neves, M.P.M.S.; Almeida, A.; Faustino, M.A.F. Revisiting current photoactive materials for antimicrobial photodynamic therapy. Molecules 2018, 23, 2424. [CrossRef] [PubMed]

22. De Rosa, M.C.; Crutchley, R.J. Photosensitized singlet oxygen and its applications. Coord. Chem. Rev. 2002, 233-234, 351-371. [CrossRef]

23. Day, R.A.; Estabrook, D.A.; Logan, J.K.; Sletten, E.M. Fluorous photosensitizers enhance photodynamic therapy with perfluorocarbon nanoemulsions. Chem. Commun. 2017, 53, 13043-13046. [CrossRef] [PubMed]

24. Costa, L.D.; Silva, J.A.; Fonseca, S.M.; Arranja, C.T.; Urbano, A.M.; Sobral, A.J.F.N. Photophysical characterization and in vitro phototoxicity evaluation of 5,10,15,20-tetra(quinolin-2-yl)porphyrin as a potential sensitizer for photodynamic therapy. Molecules 2016, 21. [CrossRef] [PubMed]

25. Chitgupi, U.; Lovell, J.F.; Rajendiran, V. Assessing photosensitizer targeting using meso-tetra(Carboxyphenyl) porphyrin. Molecules 2018, 23, 892. [CrossRef] [PubMed]

26. Shi, L.; Jiang, Y.Y.; Jiang, T.; Yin, W.; Yang, J.P.; Cao, M.L.; Fang, Y.Q.; Liu, H.Y. Water-soluble manganese and iron mesotetrakis(carboxyl)porphyrin: DNA binding, oxidative cleavage, and cytotoxic activities. Molecules 2017, 22, 1084. [CrossRef] [PubMed]

27. Garfias-Gonzalez, K.I.; Organista-Mateos, U.; Borja-Miranda, A.; Gomez-Vidales, V.; Hernandez-Ortega, S.; Cortez-Maya, S.; Martínez-García, M. High fluorescent porphyrin-PAMAM-fluorene dendrimers. Molecules 2015, 20, 8548-8559. [CrossRef] [PubMed]

28. Silva, J.N.; Galmiche, A.; Tomé, J.P.C.; Boullier, A.; Neves, M.G.P.M.S.; Silva, E.M.P.; Capiod, J.C.; Cavaleiro, J.A.S.; Santus, R.; Mazière, J.C.; et al. Chain-dependent photocytotoxicity of tricationic porphyrin conjugates and related mechanisms of cell death in proliferating human skin keratinocytes. Biochem. Pharmacol. 2010, 80, 1373-1385. [CrossRef] [PubMed]

29. Castro, K.A.D.F.; Simões, M.M.Q.; Neves, M.G.P.M.S.; Cavaleiro, J.A.S.; Ribeiro, R.R.; Wypych, F.; Nakagaki, S. Synthesis of new metalloporphyrin derivatives from [5,10,15,20-tetrakis (pentafluorophenyl)porphyrin] and 4-mercaptobenzoic acid for homogeneous and heterogeneous catalysis. Appl. Catal. A Gen. 2015, 503, 9-19. [CrossRef]

30. Breslow, R.; Gabriele, B.; Yang, J. Geometrically directed selective steroid hydroxylation with high turnover by a fluorinated artificial cytochrome P-450. Tetrahedron Lett. 1998, 39, 2887-2890. [CrossRef]

31. Battioni, P.; Brigaud, O.; Desvaux, H.; Mansuy, D.; Traylor, T.G. Preparation of functionalized polyhalogenated tetraaryl-porphyrins by selective substitution of the p-Fluorines of meso-tetra(pentafluorophenyl)porphyrins. Tetrahedron Lett. 1991, 32, 2893-2896. [CrossRef]

32. Auras, B.L.; Meller, S.L.; da Silva, M.P.; Neves, A.; Cocca, L.H.Z.; De Boni, L.; da Silveira, C.H.; Iglesias, B.A. Synthesis, spectroscopic/electrochemical characterization and DNA interaction study of novel ferrocenyl-substituted porphyrins. Appl. Organomet. Chem. 2018, 32, 1-12. [CrossRef]

33. Azenha, E.G.; Serra, A.C.; Pineiro, M.; Pereira, M.M.; Melo, J.S.; Arnaut, L.G.; Formosinho, S.J.; Gonsalves, A.M.R. Heavy-atom effects on metalloporphyrins and polyhalogenated porphyrins. Chem. Phys. 2002, 280, 177-190. [CrossRef]

34. Monteiro, C.J.P.; Pina, J.; Pereira, M.M.; Arnaut, L.G. On the singlet states of porphyrins, chlorins and bacteriochlorins and their ability to harvest red/infrared light. Photochem. Photobiol. Sci. 2012, 11, 1233-1238. [CrossRef] [PubMed] 
35. Gomes, M.C.; Silva, S.; Faustino, M.A.F.; Neves, M.G.P.M.S.; Almeida, A.; Cavaleiro, J.A.S.; Tomé, J.P.C.; Cunha, Â. Cationic galactoporphyrin photosensitisers against UV-B resistant bacteria: Oxidation of lipids and proteins by 1O2. Photochem. Photobiol. Sci. 2013, 12, 262-271. [CrossRef] [PubMed]

36. Pivetta, R.C.; Auras, B.L.; de Souza, B.; Neves, A.; Nunes, F.S.; Cocca, L.H.Z.; de Boni, L.; Iglesias, B.A. Synthesis, photophysical properties and spectroelectrochemical characterization of 10-(4-methyl-bipyridyl)-5,15-(pentafluorophenyl)corrole. J. Photochem. Photobiol. A Chem. 2017, 332, 306-315. [CrossRef]

37. Spiller, W.; Kliesch, H.; Wohrle, D.; Hackbarth, S.; Roder, B.; Schnurpfeil, G. Singlet oxyg en quantum yields of different photo- sensitizers in polar solvents and mic ellar solutions. J. Porphyr. Phthalocyanines 1998, 2, 145-158. [CrossRef]

38. Preuß, A.; Saltsman, I.; Mahammed, A.; Pfitzner, M.; Goldberg, I.; Gross, Z.; Röder, B. Photodynamic inactivation of mold fungi spores by newly developed charged corroles. J. Photochem. Photobiol. B Biol. 2014, 133, 39-46. [CrossRef] [PubMed]

39. Grancho, J.C.P.; Pereira, M.M.; da Miguel, M.G.; Rocha, G.A.M.; Burrows, H.D. Synthesis, spectra and photophysics of some free base tetrafluoroalkyl and tetrafluoroaryl porphyrins with potential applications in imaging. Photochem. Photobiol. 2002, 75, 249-256. [CrossRef]

40. Pineiro, M.; Pereira, M.M.; Rocha Gonsalves, A.M.D.A.; Arnaut, L.G.; Formosinho, S.J. Singlet oxygen quantum yields from halogenated chlorins: Potential new photodynamic therapy agents. J. Photochem. Photobiol. A Chem. 2001, 138, 147-157. [CrossRef]

41. Cavaleiro, J.A.S.; Görner, H.; Lacerda, P.S.S.; MacDonald, J.G.; Mark, G.; Neves, M.G.P.M.S.; Nohr, R.S.; Schuchmann, H.P.; Von Sonntag, C.; Tomé, A.C. Singlet oxygen formation and photostability of meso-tetraarylporphyrin derivatives and their copper complexes. J. Photochem. Photobiol. A Chem. 2001, 144, 131-140. [CrossRef]

42. Pineiro, M.; Carvalho, A.L.; Pereira, M.M.; Rocha Gonsalves, A.M.D.A.; Arnaut, L.G.; Formosinho, S.J. Photoacoustic measurements of porphyrin triplet-state quantum yields and singlet-oxygen efficiencies. Chem. A Eur. J. 1998, 4, 2299-2307. [CrossRef]

43. Auras, B.L.; Oliveira, V.A.; Terenzi, H.; Neves, A.; Iglesias, B.A. Meso-Mono-[4-(1,4,7-triazacyclononanyl)]tri(phenyl)]porphyrin and the respective zinc(ii)-complex: Complete characterization and biomolecules binding abilities. Photochem. Photobiol. Sci. 2016, 15, 564-579. [CrossRef] [PubMed]

44. Arba, M.; Tjahjono, D.H. The binding modes of cationic porphyrin-anthraquinone hybrids to DNA duplexes: In silico study. J. Biomol. Struct. Dyn. 2015, 33, 657-665. [CrossRef] [PubMed]

45. Bennett, M.; Krah, A.; Wien, F.; Garman, E.; McKenna, R.; Sanderson, M.; Neidle, S. A DNA-porphyrin minor-groove complex at atomic resolution: The structural consequences of porphyrin ruffling. Proc. Natl. Acad. Sci. USA 2000, 97, 9476-9481. [CrossRef] [PubMed]

46. Bissantz, C.; Kuhn, B.; Stahl, M. A medicinal chemist's guide to molecular interactions. J. Med. Chem. 2010, 53, 5061-5084. [CrossRef] [PubMed]

47. Mocilac, P.; Osman, I.A.; Gallagher, J.F. Short C-H * F interactions involving the 2,5-difluorobenzene group: Understanding the role of fluorine in aggregation and complex C-F/C-H disorder in a $2 \times 6$ isomer grid. CrystEngComm. 2016, 18, 5764-5776. [CrossRef]

48. Thalladi, V.R.; Weiss, H.C.; Bläser, D.; Boese, R.; Nangia, A.; Desiraju, G.R. C-H...F interactions in the crystal structures of some fluorobenzenes. J. Am. Chem. Soc. 1998, 120, 8702-8710. [CrossRef]

49. Boer, D.R.; Canals, A.; Coll, M. DNA-binding drugs caught in action: The latest 3D pictures of drug-DNA complexes. Dalton Trans. 2009, 399-414. [CrossRef] [PubMed]

Sample Availability: Not available. 